\title{
COSSON, Rildo. Paradigmas do ensino da literatura. São Paulo: Contexto, 2020.
}

\author{
Isabella Bacha Ferreira \\ Doutoranda \\ Universidade Nove de Julho, UNINOVE \\ São Paulo, SP - Brasil \\ bachafisabella@hotmail.com \\ Maurício Silva \\ Doutor \\ Universidade Nove de Julho, UNINOVE \\ São Paulo, SP - Brasil \\ maurisil@gmail.com
}

\section{Para citar- (ABNT NBR 6023:2018)}

FERREIRA, Isabella Bacha; SILVA, Maurício. Resenha. Eccos - Revista Cientifica, São Paulo, n. 59, p. 1-4, e21062, jul./set., 2021. Resenha. COSSON, Rildo. Paradigmas do ensino da literatura. São Paulo: Contexto, 2020. https://doi.org/10.5585/eccos.n59.21062.

Rildo Cosson se destaca como um dos autores referenciais no que diz respeito ao ensino de literatura no Brasil. Dentre suas publicações na área mencionada, o autor lançou, em 2020, o livro Paradigmas do ensino da literatura, que expõe as estruturas que marcaram o ensino de literatura ao longo da história da educação brasileira.

Com uma linguagem clara e objetiva, o livro é divido em seis capítulos que marcam, em ordem linear, o contexto histórico de cada paradigma da história do ensino de literatura no Brasil, mais a introdução e a conclusão. Os dois primeiros capítulos referem-se aos paradigmas que são característicos de tempos mais remotos, são eles: moral-gramatical e históriconacional, enquanto os próximos quatro são inerentes à contemporaneidade, sendo: analíticotextual, social-identitário, formação do leitor e letramento literário, que foram estabelecidos ao final do século XX.

Cada capítulo que se refere aos paradigmas citados acima busca esclarecer pontos importantes no ensino de literatura, como os conceitos básicos, os papéis do professor, do aluno e da escola, as atividades em sala de aula, os métodos de avaliação, a seleção dos textos para o 
ensino, dentre uma série de questões que envolvem toda a relação de ensino que eram usadas como estratégias pelo professor, além de esclarecer como essas estratégias eram recebidas pelo alunado.

Os dois primeiros capítulos dizem respeito aos paradigmas que condizem com uma sociedade que, no século XIX, era extremamente conservadora e priorizava os costumes da fé católica, bem como a imposição de padrões culturais e elitista a serem seguidos.

Seguindo a sequência da obra, o primeiro paradigma é o moral-gramatical. Embora seja um modelo educacional muito usado no período colonial, não é difícil encontrarmos sistemas educacionais que priorizem o ensino de literatura para a memorização da escrita da norma considerada culta e formar moralmente padrões éticos pautados na fé cristã, o que gera uma elitização da literatura, tornando acessível para poucas pessoas. A grande contradição desse paradigma, mencionada pelo autor, é que a estratégia de ensino afasta os alunos de conhecimentos que são fundamentais para que enfrentem problemas do presente.

O segundo paradigma é o histórico-nacional, que tem características semelhantes ao moral-gramatical. $\mathrm{O}$ que difere os dois primeiros paradigmas do livro é o fato de existir, no paradigma histórico-nacional, a necessidade de os textos literários trabalhados em sala de aula serem exclusivamente nacionais, no intuito de formar o leitor para o conhecimento das "brasilidades".

Ambos possuem características que se associam ao que Paulo Freire considera como concepção bancária da educação, porque destacam o papel do professor como aquele que transfere conhecimento para o aluno, que por sua vez tem uma função "passiva" ao receber o conhecimento.

$\mathrm{Na}$ segunda metade do século XX começa a haver maiores mudanças nos sistemas educacionais e, consequentemente, no ensino de literatura. No paradigma analítico-textual, o primeiro do tempo contemporâneo, observa-se uma ruptura no que diz respeito às tradições conservadoras, embora ainda apresente um caráter um tanto quanto elitista, uma vez que se preocupa com o estilo linguístico dos textos. Nas palavras do autor

podem ser colocadas definições mais sofisticadas, como os conceitos de literariedade ou estranhamento dos formalistas russos - a propriedade de linguagem que caracteriza as obras literárias ou as características que distinguem a linguagem literária da linguagem ordinária - e de função poética de Roman Jakobson - quando o texto se volta para si mesmo ou tem a elaboração da mensagem como função dominante -, que alimentam as várias concepções imanentistas da literatura ou que, pelo menos, buscam defini-la como uma linguagem específica, reforçando os critérios de base linguísticotextual. (p.74) 
Para além da preocupação com linguagem presente nas obras, é um paradigma que possui rupturas com os dois primeiros citados. Aqui, a literatura é entendida como um conjunto de obras que são escolhidas e que não se baseiam mais pela autoridade de autores considerados cânones, como nos dois primeiros paradigmas, tampouco pela nacionalidade do autor.

No quarto capítulo, referente ao paradigma social-identitário, Cosson o sinaliza como o primeiro paradigma que considera o ensino de literatura um importante aliado "em busca de uma sociedade mais justa e igualitária" (p.101). É o primeiro paradigma que tem como prioridade a formação do cidadão engajado politicamente, no sentido de colaborar para uma sociedade plural e democrática.

Embora seja, também, o primeiro paradigma que leva em consideração a representatividade de grupos que antes eram excluídos do ensino de literatura por não atenderem aos padrões estabelecidos pela fé, como nos dois primeiros paradigmas do livro, e que considera a participação ativa e colaborativa do aluno, existe um conflito, pois

se por um lado, a exigência de participação e a construção colaborativa do
conhecimento são aspectos positivos porque envolvem ativamente o aluno processo
pedagógico; por outro, quando não há adesão voluntária ao texto e à análise crítica
proposta, esses mesmos procedimentos podem servir para a doutrinação dos alunos.
(p.108)

É preciso muita cautela ao mediar os debates e as problematizações acerca das obras trabalhadas na escola. Além disso, existe a necessidade de uma disciplina específica para a literatura, uma vez que a disciplina não assume a função do ensino da Língua Portuguesa. O autor destaca autores que criticam o ensino superior dos cursos de Letras que, em sua maioria, não condizem com o ensino de literatura que os futuros professores usarão nas suas práticas em sala de aula.

No início dos anos 1980, em um contexto de crise do ensino de leitura, começou a ser propagado o paradigma da formação do leitor, o quinto paradigma do livro, que apresenta uma estratégia de ensino que se difere dos demais no sentido de fazer uso de obras para o ensino de leitura desde os anos iniciais da educação. Nesse caso, o uso de obras cânones não é imposto aos alunos, uma vez que esse modelo busca “ensinar" o prazer pela leitura, e considera o gosto pessoal dos alunos. Rildo Cosson esclarece que essa estrutura de ensino se apoia na teoria de "Vygotsky e seus divulgadores, de onde parece emergir o conceito de mediação como instrumento do desenvolvimento do leitor" (p.164) e também se apoia do no pensamento de Paulo Freire, uma vez que garante o protagonismo do aluno como leitor crítico. Além disso, os alunos são livres para escolherem quais livros serão lidos. $\mathrm{O}$ autor explica que 
O ideal libertário dessa prática de leitura é ainda reforçado pela ausência de hierarquias e pelo compartilhamento de gostos que ela proporciona colocando alunos e professores em um mesmo 'nível', ainda que tenham diferentes repertórios e experiências de leitura de textos literários. (p.137)

É no paradigma da formação do leitor em que é mais evidenciada a interação do aluno com o texto, "que faz esse novo ensino ser essencialmente pragmático e participativo" (p. 139). É importante ressaltar que as escolhas pelas obras lidas não se dão em todos os anos escolares. No ensino médio, tende-se aos textos literários que se enquadram no paradigma históriconacional.

Finalmente, o último capítulo do livro diz respeito do paradigma do letramento literário, cujo termo foi denominado por Graça Paulino no fim dos anos 1990. Cosson elucida que esse modelo de ensino é o que mais se afasta "das várias limitações que os outros paradigmas implícita ou explicitamente estabeleciam para o manuseio das obras literárias na escola" (p. 177). Isso porque considera os textos literários tidos como clássicos e cânones, mas também considera, na mesma proporção, os textos que refletem "uma comunidade e sua herança cultural” (p. 175). É importante ressaltar, que dentro da concepção do letramento literário, outras formas de textos são validadas, como os "vídeos, filmes, produtos digitais, voz e até corpo" (p. 175).

Nesse paradigma, valoriza-se a bagagem literária que o aluno carrega, bem como as experiências de vida que ele traz consigo. Nesse sentido, é importante que as obras escolhidas para o ensino de literatura sejam condizentes com a realidade da escola e dos alunos. Por isso, escolas e professores possuem autonomia na seleção das obras a serem trabalhadas. É a partir do letramento literário que o aluno se torna "o principal agente do processo pedagógico" (p. 191).

O livro de Cosson é uma seleção dos paradigmas que marcaram o ensino de literatura no Brasil. É fundamental porque nos mostra que a literatura também avançou com as transformações do mundo, assim como o ensino dela também foi se transformando. Paradigmas do Ensino da Literatura é um importante instrumento para que os professores de ensino de literatura (re) pensem suas práticas pedagógicas, pois permite que construam respostas para os desafios encontrados ao ensinar literatura em sala de aula. Para os pesquisadores, temos aqui uma obra embasada que esclarecerá a importância da continuidade da pesquisa para o ensino de literatura. 